\title{
Body iron status indicators and inflammation indicators during inflammatory bowel disease therapy in children and adolescents
}

\author{
Fernanda F CORRÊA and Vera L SDEPANIAN
}

Received: 26 July 2020 Accepted: 9 October 2020

\begin{abstract}
Background - The treatment of patients with inflammatory bowel disease (IBD) consists of the induction and maintenance remission of the disease. Iron status indicators would be useful for the diagnosis of iron deficiency anemia, whereas the inflammation indicators would be for the diagnosis of chronic disease anemia. Objective - To assess body iron status indicators and inflammation indicators during the treatment of IBD, consisted of conventional or infliximab therapy in children and adolescents. Methods - A case-control study of a sample of 116 individuals, of which 81 patients with IBD, 18 of them receiving conventional therapy, 20 infliximab therapy, and 43 who were in remission of the disease, and 35 healthy (control group) children and adolescents. Iron status and inflammation indicators were investigated at baseline, and 2 and 6 months of both therapies - conventional and infliximab. Results - The mean age was 12.1 \pm 4.3 years. At baseline, both groups - conventional therapy and infliximab - presented significant differences in most markers studied compared to the control group. After 2 months of conventional therapy, hemoglobin and serum iron levels were lower than those of the control group; and red cells distribution width (RDW), total iron-binding capacity, transferrin receptor/ferritin ratio, and interleukin-6 were higher than the control group. After 2 months of infliximab treatment, hemoglobin and serum iron levels were lower than those of the control group; and RDW, soluble transferrin receptor, soluble transferrin receptor/ferritin ratio, and interleukin- 6 were higher than the control group. After 6 months of conventional therapy, hemoglobin and serum iron levels were lower than those of the control group, and RDW and interleukin-6 were higher than those of the control group. After 6 months of infliximab treatment, the hemoglobin and serum iron levels were lower than the control group, and RDW, soluble transferrin receptor, soluble transferrin receptor/ferritin ratio, erythrocyte sedimentation rate, and platelets were higher than the control group. Regarding patients under treatment for at least one year (remission group), all markers studied, except transferrin, were similar to the control group. Conclusion - In conclusion, there were some contradictions among the different body iron status indicators and inflammation indicators at two and 6 months of treatment with conventional and infliximab therapy, however after one year of treatment, as shown by the remission group, all indicators studied, except transferrin, were similar to healthy children and adolescents.
\end{abstract}

HEADINGS - Inflammatory bowel diseases, therapy. Iron-deficiency anemia. Child. Adolescent.

\section{INTRODUCTION}

Crohn disease and ulcerative colitis are chronic diseases associated with a high risk of complications ${ }^{(1-3)}$, with a consequent need for surgery and hospitalization ${ }^{(4)}$. The treatment of patients with inflammatory bowel disease (IBD) consists of the induction and maintenance remission of the disease, aimed at the healing of mucosa and improving intestinal and extra-intestinal manifestations ${ }^{(5-7)}$ as low bone mineral density, growth deficit, pubertal delay, and anemia.

In order to assess anemia in IBD, the most useful body iron status indicators are transferrin saturation ${ }^{(8-10)}$, soluble transferrin receptor $(\mathrm{sTfR})^{(11-21)}$, serum iron ${ }^{(11,12,17,22-24)}$, soluble transferrin receptor/ ferritin ratio (sTfR-SF) ${ }^{(12,14,16,17,25)}$ and transferrin ${ }^{(17,26,27)}$; while erythrocyte sedimentation rate (ESR) ${ }^{(11,17,22,23,26,28)}$, interleukin-6 $(\text { IL-6) })^{(22,24,26)}$, ferritin ${ }^{(11,12,16,17,23-30)}$, albumin ${ }^{(24)}$ and platelets ${ }^{(31)}$ are considered inflammation indicators. The iron status indicators would be useful for the diagnosis of iron deficiency anemia, whereas inflammation indicators would be for the diagnosis of anemia of the chronic disease, also known as anemia of inflammation ${ }^{(32)}$.

Literature about the influence of conventional or biologic therapy -infliximab - in anemia of patients with IBD is scarce. In adults with IBD, one study demonstrated that, after 14 weeks of treatment with infliximab, the occurrence of anemia decreased due to the control of disease activity, according to the parameters studied - ESR, ferritin and C-reactive protein (CRP) ${ }^{(28)}$. Another study in children and adolescents with Crohn disease, which assessed hemoglobin, hematocrit, mean corpuscular volume (MCV), and serum iron, found an increased concentration of serum iron after conventional three-month therapy (corticosteroid and/or thiopurine) ${ }^{(33)}$.

Due to lack of studies that analyzed iron status indicators and inflammation indicators, during the treatment of IBD in pediatric patients, we decided to do this study aiming to assess body iron status indicators and inflammation indicators during the treatment of IBD, consisted of conventional or infliximab therapy in children and adolescents. 


\section{METHODS}

\section{Patient population and study design}

A case-control study, from July 2007 to January 2013, that consecutively included all outpatients followed up at a specialized clinic of pediatric IBD, 2-20 years old incomplete, of both genders, at the start of treatment with conventional therapy - corticosteroid and/or azathioprine and/or mesalazine - (conventional therapy group) or biologic treatment with infliximab (infliximab group) for IBD, confirmed by the set of clinical, endoscopic, pathological and imaging criteria. All the patients included in these groups with Crohn disease ${ }^{(34)}$ presented Pediatric Crohn's Disease Activity Index (PCDAI) greater than 30, and those with ulcerative colitis ${ }^{(35)}$ presented Pediatric Ulcerative Colitis Activity Index (PUCAI) greater than 65, at the baseline. We also included, consecutively, all outpatients with a confirmed diagnosis of IBD under treatment with conventional or infliximab therapy for more than one year who were in remission of disease (remission group). All the patients of this group presented disease activity indexes, PCDAI and PUCAI, lower than 10. As for exclusion criteria, patients with IBD who presented any other chronic associated disease were excluded.

We also studied a control group of healthy children and adolescents, who did not present either chronic disease or anemia, from a full-time school, located in the south of the city of São Paulo, that was the same location of the outpatient clinic of this study. This group's selection consisted of detailed clinical evaluation for signs of anemia - skin pallor, conjunctiva pallor, lip, and tongue pallor $^{(36)}$. Therefore, patients without clinical signs of anemia or chronic disease were matched for gender and age with the study group and invited to participate in the project. Those who accepted the invitation were scheduled for blood collection at their school.

Therefore, the sample of this study comprised 116 individuals as follows: 18 patients in the conventional therapy group ( 7 with Crohn disease and 11 with ulcerative colitis); 20 patients in the infliximab group (all with Crohn disease); 43 patients in the remission group - 21 patients receiving conventional therapy and 22 receiving infliximab therapy (all with Crohn disease), (28/43 with Crohn disease and 15/43 with ulcerative colitis), and 35 healthy individuals in the control group.

\section{Methods}

In addition to the hemoglobin and red cells distribution width (RDW), the following indicators were assessed in all groups: transferrin saturation, sTfR, serum iron, total iron-binding capacity (TIBC), sTfR-SF, transferrin, ESR, IL-6, ferritin, albumin, and platelets. In addition to these laboratory parameters, we also assessed the intake and absorption of iron. It is interesting to note that the formula to calculate the sTfR-SF is bellow ${ }^{(37)}$.

\section{sTfR-SF $=\log$ soluble transferrin receptor $(\mu / L)$ ferritin $(\mu / L)$}

Right after the collection of blood sampling for the tests described before, at the baseline, with the patient still in the fasting state, the iron absorption was examined. So, the ferrous sulfate was administered orally ( $1 \mathrm{mg}$ of elemental iron $/ \mathrm{kg}$ - maximum $25 \mathrm{mg}$ of elemental iron), and, after two hours, the serum iron was measured again $^{(38-40)}$. It was arbitrarily established that the iron absorption test was the difference between serum iron after iron overload and initial serum iron.
The patients of the conventional therapy and infliximab groups were assessed at the baseline (just before treatment starts), after 2 months and 6 months of treatment. The patients of the remission group were assessed after at least one year of treatment, and the control group was investigated only once.

PCDAI and PUCAI indices were assessed in all the patients of the conventional and infliximab therapy groups, after 6 months of the treatment start. According to the classification of Paris, patients were assessed regarding the location of the disease ${ }^{(41)}$. The methodology used in the analysis of laboratory tests is described below. Blood counts were performed by automated analysis using ADVIA 120 analyzer, and serum iron through the colorimetric method using ADVIA 1650 analyzer. Total iron-binding capacity was established using the formula: total iron-binding capacity $=($ transferrin - serum iron $)$. The ferritin concentration was obtained by the chemiluminescence method using the ADVIA Centaur unit, and the measurement of transferrin was determined by turbidimetry using ADVIA 1650 analyzer. Transferrin saturation was determined using the following formula:

$$
\text { transferrin saturation }=\frac{\text { serum iron }}{\mathrm{TIBC}} \times 100
$$

The dosage of the sTfR was made in duplicate and obtained using the ELISA test (Kit for measurement of soluble human transferrin R DTFR 1 - LGC Scientific Supply). The concentration of IL-6 was determined using the ELISA test (R\&D Systems Quantikine D6050 ELISA Kit; Minneapolis, MN), in duplicate, and the methodology was followed as determined by the manufacturer. ESR was obtained by automated analysis using the Spife device, and protein electrophoresis was determined by electrophoretic fractionation on agarose gel with densitometry reading.

All the anemic patients used iron medication in therapeutic doses of the elemental iron. The intake of dietary iron was assessed using the dietary survey called "usual daily diet" in the infliximab and conventional therapy groups at baseline and after 2 and 6 months of treatment. The dietary iron intake was calculated by computer program NutWin ${ }^{\circledR}$ version 2.5 (NutWin Software, Nutrition Support Program, Escola Paulista de Medicina, São Paulo, Brazil, 2002). We used Dietary Reference Intake (DRI) ${ }^{(42)}$ as the reference standard for evaluating the recommended values.

\section{Statistical analysis}

There was no normal distribution of all quantitative variables (Kolmogorov Smirnov test), and, therefore, we used the KruskalWallis test when comparing the means of the four groups; if there were any differences between them, multiple comparisons were made using the Tukey test. The comparison of the prevalence of anemia among the groups was assessed using Fischer's test.

Statistical calculations were performed using the SPSS version 11.5.0 programs (SPSS Inc., Chicago, IL), and the significance level was set at 0.05 or $5 \%$ rejection level of the null hypothesis.

\section{Ethical considerations}

The Research Ethics Committee of the Federal University of Sao Paulo approved the project - CEP/ UNIFESP n:0524/07 and $\mathrm{n}: 1233 / 09$, and all those responsible for the patients freely agreed to the terms of the consent/assent form with all questions being answered beforehand. 


\section{RESULTS}

TABLE 1 shows the demographic and baseline characteristics of the population. The mean age of the patients was $12.1 \pm 4.3$ years. By the classification of Paris ${ }^{(4)}$, all patients with Crohn disease, at baseline, presented ileocolonic disease (L3), non-stenotic, and nonpenetrating type (B1), while all patients with ulcerative colitis presented pancolitis (E4) and severe type (S1).

Considering the limits of anemia by age, by the $\mathrm{WHO}^{(32)}$, the proportion of anemic patients in the conventional therapy group at baseline was $61 \%$ (11/18), after 2 months of treatment was $33.3 \%$ $(6 / 18)$ and after 6 months of treatment was $27.7 \%(5 / 18)$. In the infliximab group, $50 \%(10 / 20)$ of the patients presented anemia at baseline, $50 \%(10 / 20)$ of the patients presented anemia after 2 months of treatment, and $60 \%(12 / 20)$ of the patients presented anemia after 6 months of treatment. Therefore, there was no statistically significant difference between the proportion of anemic patients: at baseline of the conventional therapy group and baseline of the infliximab group $(P=0.718)$; after 2 months of the treatment with conventional therapy and after 2 months of the treatment with infliximab $(P=0.478)$; nor after 6 months of treatment with conventional therapy and after 6 months of treatment with infliximab $(P=0.095)$. In the remission group, the proportion of anemia was equal to $18.6 \%(8 / 43)$. The proportion of anemic patients of the infliximab group after 6 months of treatment was statistically higher than that of anemic patients in the remission group $(P=0.003)$. In contrast, there was no statistically significant difference in the proportion of anemic patients of the conventional therapy group after 6 months of treatment and of the remission group $(P=0.649)$.

As shown in TABLE 1, at baseline, both groups - conventional therapy and infliximab - presented significant differences in respect of most markers studied compared to the healthy group.

After 2 months of conventional therapy (TABLE2), hemoglobin and serum iron levels were lower than those of the control group; and RDW, TIBC, sTfR-SF, and IL-6 were higher than the control group. After 2 months of infliximab treatment (TABLE 2), hemoglobin and serum iron levels were lower than those of the control group; and RDW, sTfR, sTfR-SF, and IL-6 were higher than the control group.

The TABLE 3 demonstrated that after 6 months of conventional therapy, hemoglobin and serum iron levels were lower than those of the control group, and RDW and IL- 6 were higher than those of the control group. After 6 months of infliximab treatment (TABLE 3), the hemoglobin and serum iron levels were lower than the control group, and RDW, sTfR, sTfR-SF, ESR, and platelets were higher than the control group. All patients of the conventional therapy group and the infliximab group, after 6 months of treatment, presented PCDAI and PUCAI lower than 10, so all of them were in remission of disease, according to these activity indices.

Regarding patients under treatment for at least one year (remission group), all markers studied, except transferrin, were similar to the control group (TABLE 1).

TABLE 1. Demographic and baseline characteristics of body iron status indicators and inflammation indicators of the patients with inflammatory bowel disease, according to the four studied groups.

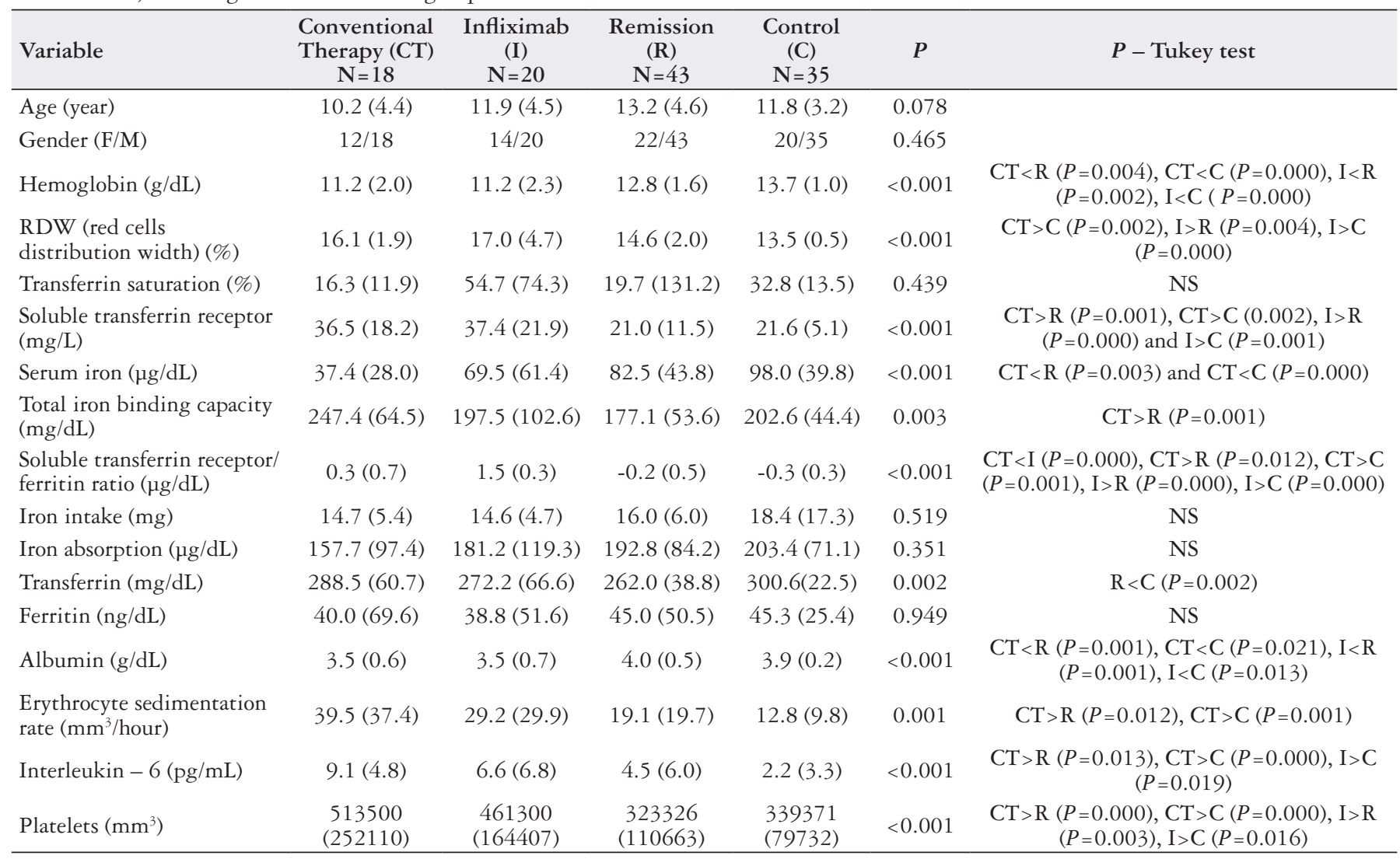

Values correspond to the number of patients and means (SD). NS: non-significant. 
TABLE 2. Characteristics, after two months of treatment, of body iron status indicators and inflammation indicators of the patients with inflammatory bowel disease, according to the four studied groups.

\begin{tabular}{|c|c|c|c|c|c|c|}
\hline Variable & $\begin{array}{l}\text { Conventional } \\
\text { Therapy (CT) } \\
\mathrm{N}=18\end{array}$ & $\begin{array}{l}\text { Infliximab } \\
\text { (I) } \\
\mathrm{N}=20 \\
\end{array}$ & $\begin{array}{c}\text { Remission } \\
(\mathrm{R}) \\
\mathrm{N}=43 \\
\end{array}$ & $\begin{array}{l}\text { Control } \\
\text { (C) } \\
\mathrm{N}=35 \\
\end{array}$ & $P$ & $P$ - Tukey Test \\
\hline Hemoglobin $(\mathrm{g} / \mathrm{dL})$ & $12.4(2.0)$ & $11.1(2.7)$ & $12.8(1.6)$ & $13.7(1.0)$ & $<0.001$ & $\begin{array}{c}\mathrm{I}<\mathrm{R}(P=0.002), \\
(P=0.000)\end{array}$ \\
\hline $\begin{array}{l}\text { RDW (red cells } \\
\text { distribution width) }(\%)\end{array}$ & $16.6(2.0)$ & $17.1(3.8)$ & $14.6(2.0)$ & $13.5(0.5)$ & $<0.001$ & $\begin{array}{c}\mathrm{CT}>\mathrm{R}(P=0.007), \mathrm{CT}>\mathrm{C}(P=0.000), \mathrm{I}>\mathrm{R} \\
(P=0.000) \text { and } \mathrm{I}>\mathrm{C}(P=0.000)\end{array}$ \\
\hline Transferrin saturation (\%) & $20.3(12.2)$ & $-3.0(107.0)$ & $19.7(131.2)$ & $32.8(13.5)$ & 0.001 & $*$ \\
\hline Serum iron $(\mu \mathrm{g} / \mathrm{dL})$ & $58.0(33.9)$ & $57.2(41.4)$ & $82.5(43.8)$ & $98.0(39.8)$ & 0.002 & $\mathrm{CT}<\mathrm{C}(P=0.005)$ and $\mathrm{I}<\mathrm{C}(P=0.003)$ \\
\hline $\begin{array}{l}\text { Total iron binding capacity } \\
(\mathrm{mg} / \mathrm{dL})\end{array}$ & $252.4(62.6)$ & $206.2(83.0)$ & $177.1(53.6)$ & $202.6(44.4)$ & 0.001 & $\mathrm{CT}>\mathrm{R}(P=0.000)$ and $\mathrm{CT}>\mathrm{C}(P=0.021)$ \\
\hline $\begin{array}{l}\text { Soluble transferrin } \\
\text { receptor/ferritin } \\
\text { ratio }(\mu \mathrm{g} / \mathrm{dL})\end{array}$ & $0.2(0.4)$ & $1.5(0.4)$ & $-0.2(0.5)$ & $-0.3(0.3)$ & $<0.001$ & $\begin{array}{c}\mathrm{CT}<\mathrm{I}(P=0.000), \mathrm{CT}>\mathrm{R}(P=0.042), \mathrm{CT}>\mathrm{C} \\
(P=0.006), \mathrm{I}>\mathrm{R}(P=0.000) \text { and } \mathrm{I}>\mathrm{C} \\
(P=0.000)\end{array}$ \\
\hline Albumin $(\mathrm{g} / \mathrm{dL})$ & $6.4(12.3)$ & $3.3(0.7)$ & $4.0(0.5)$ & $3.9(0.2)$ & $<0.001$ & $*$ \\
\hline $\begin{array}{l}\text { Erythrocyte sedimentation } \\
\text { rate }\left(\mathrm{mm}^{3} / \text { hour }\right)\end{array}$ & $24.1(24.5)$ & $25.6(21.7)$ & $19.1(19.7)$ & $12.8(9.8)$ & 0.114 & NS \\
\hline Interleukin $-6(\mathrm{pg} / \mathrm{mL})$ & $7.0(4.0)$ & $5.8(3.9)$ & $4.5(6.0)$ & $2.2(3.3)$ & $<0.001$ & $\mathrm{CT}>\mathrm{C}(P=0.003)$ and $\mathrm{I}>\mathrm{C}(P=0.036)$ \\
\hline Platelets $\left(\mathrm{mm}^{3}\right)$ & $\begin{array}{c}429722 \\
(191904)\end{array}$ & $\begin{array}{c}418550 \\
(179688) \\
\end{array}$ & $\begin{array}{c}323326 \\
(110663) \\
\end{array}$ & $\begin{array}{c}339371.4 \\
(79732)\end{array}$ & 0.016 & $\mathrm{CT}>\mathrm{R}(P=0.026)$ and $\mathrm{I}>\mathrm{R}(P=0.045)$ \\
\hline
\end{tabular}

Values correspond to the number of patients and means (SD). * It was not possible to detect any statistical difference. NS: non-significant.

TABLE 3. Characteristics, after six months of treatment, of body iron status indicators and inflammation indicators of the patients with inflammatory bowel disease, according to the four studied groups.

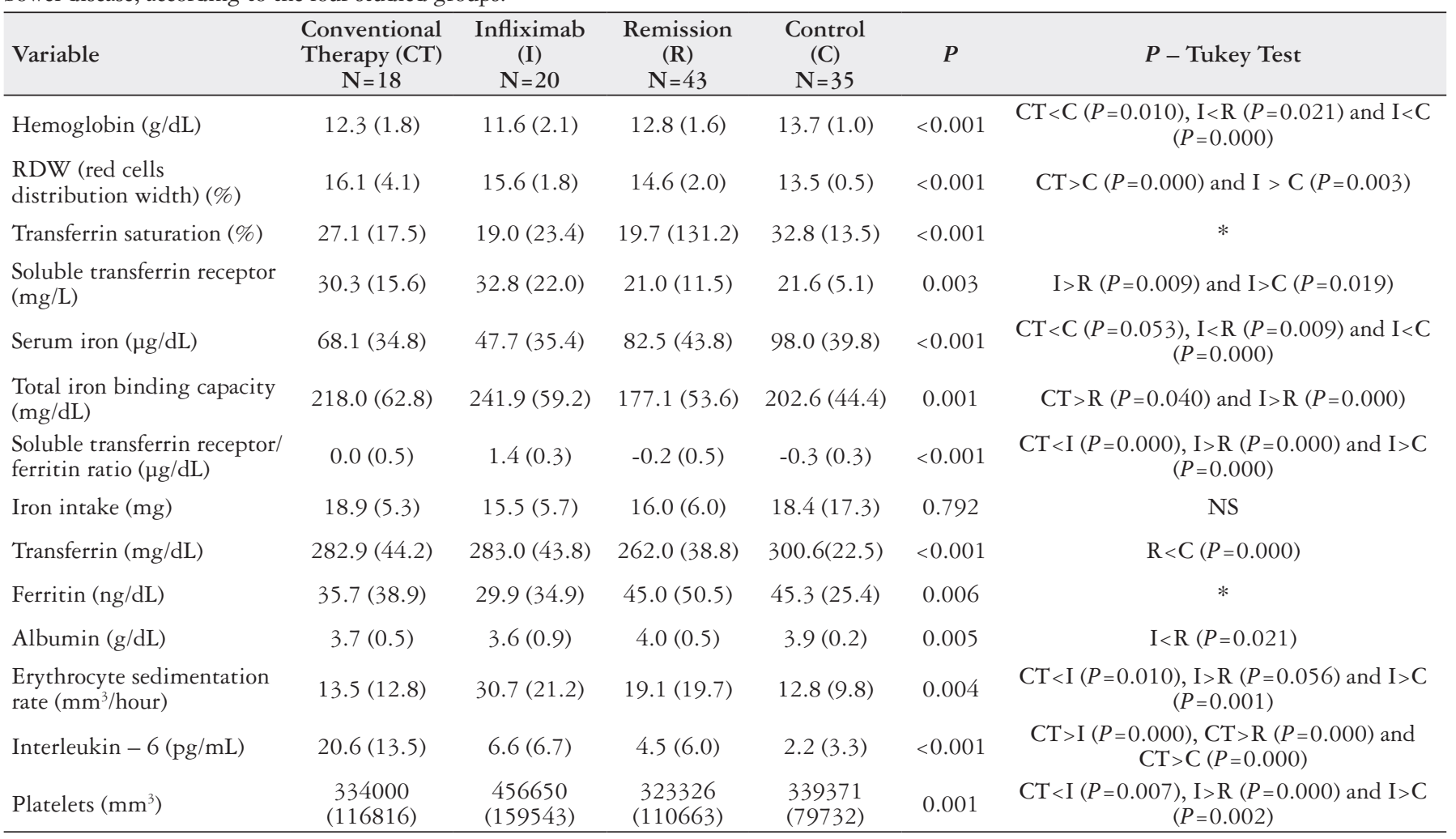

Values correspond to the number of patients and means (SD). * It was not possible to detect any statistical difference. NS: non-significant. 
There was no statistically significant difference among the four groups studied concerning the means of iron absorption (TABLE 1) and iron intake (TABLE 1, 2, and 3). Therefore, the consumption of iron was similar among these groups at all studied times.

\section{DISCUSSION}

According to our knowledge, this is the first study that evaluated the influence of conventional therapy and therapy with infliximab in children and adolescents with IBD, analyzing almost all body iron status indicators and inflammation indicators.

Patients under treatment for at least one year (remission group) were similar to those of the control group for all markers studied except for transferrin, suggesting that at least one year of conventional therapy or therapy with infliximab would be sufficient to normalize iron status indicators and inflammation indicators.

At baseline, concerning the conventional therapy group, the concentrations of hemoglobin, serum iron, and albumin were lower when compared with the control group; whereas RDW, sTfR, sTfR-SF, ESR, IL-6, and platelets presented higher concentration than those of the control group. Regarding the infliximab group, hemoglobin and albumin levels were lower compared to those of the control group; however, RDW, sTfR, sTfR-SF, IL-6, and platelets showed higher levels than those of the control group. Therefore, at baseline, the markers' behavior in the conventional and infliximab groups was different when compared with a healthy population (control), showing the presence of anemia due to iron deficiency and anemia of inflammation.

In the course of treatment, after 2 months, for the conventional therapy group, the concentration of hemoglobin and serum iron was lower when compared with that of the control group; whereas, RDW, TIBC, sTfR-SF, and IL-6 demonstrated higher levels than in the control group. As for the infliximab group, levels of hemoglobin, serum iron, and transferrin were lower than those of the control group; however, RDW, sTfR, sTfR-SF, and IL-6 presented higher levels than the control group. Therefore, the behavior of markers after 2 months of treatment, either with conventional therapy or infliximab was different from that of the control group, indicating that this time of therapy was still not enough to normalize the markers studied, persisting the occurrence of anemia due to iron deficiency and anemia of inflammation.

After 6 months of treatment, regarding the conventional therapy group, the concentration of hemoglobin and serum iron was lower than that of the control group; whereas RDW and IL-6 were higher than those in the control group. As for the infliximab group, levels of hemoglobin and serum iron were lower when compared to those of the control group; however, RDW, sTfR, sTfR-SF, ESR, and platelets presented higher levels than those of the control group. Therefore, after 6 months, the performance of markers remained virtually the same both in conventional treatment as in the treatment with infliximab, also noting alteration of inflammation indicators, which suggests that anemia of inflammation was still present after this period with both therapies. However, there was an unexpected result for the treatment with infliximab, which was different from conventional treatment. The treatment with infliximab also demonstrated alterations of the body iron status indicators even after 6 months of treatment, which had not occurred with conventional therapy. Therefore, after 6 months of treatment with conventional therapy, there was still the presence of anemia of inflammation, whereas, after treatment with infliximab, there was the presence of anemia due to iron deficiency associated with anemia of inflammation. It would be discussed that the infliximab group was worst about the IBD compared to the conventional group and that even though the activity index indicated that the infliximab group was on remission, the anemia was not solved. So, in some patients, who presented iron deficiency anemia, the intravenous iron therapy, as shown by Venturieri, et al. study ${ }^{(43)}$, would be indicated even though the patient presented normal iron absorption.

Considering that the iron absorption and iron intake in conventional therapy and infliximab groups were statistically similar to the control and remission groups, it can be inferred that the anemia was not due to low iron intake or iron absorption deficit. To the cause of anemia, the possible reason would be blood loss in the stool for the activity of IBD.

It is essential to highlight that after 6 months of treatment, the concentration of IL- 6 was higher in the conventional group compared with the control group, while there was no difference between infliximab and control group. Therefore, treatment with infliximab seems to be more effective in respecting antiinflammatory power.

Regarding the sTfR, considered one of the best indicators of iron deficiency anemia ${ }^{(21,25)}$, especially the sTfR-SF$^{(25)}$, it is interesting to note that there was higher concentration in both conventional and infliximab groups compared to remission and control group, at baseline, 2 and 6 months after treatment. One study with children ${ }^{(25)}$ showed that sTfR and sTfR/log ferritin were significantly higher in the IBD group than the control group.

It is necessary to emphasize the lack of studies published regarding indicators of iron body status and inflammation indicators during the treatment of IBD in adults, children, and adolescents. It is also important to mention that these studies evaluated small among indicators. One study showed, after 3 months and a half of the treatment with infliximab, in adults with IBD, reduction in the occurrence of anemia of inflammation, according to the parameters of ESR, ferritin, and CRP ${ }^{(26)}$. The study in children and adolescents with Crohn disease treated with conventional therapy observed increased serum iron after 3 months of treatment ${ }^{(30)}$.

Concerning iron absorption in patients with IBD, one study ${ }^{(23)}$ using a different methodology from that of the present study, also concluded that the absorption was preserved in adults with activity IBD, and another ${ }^{(22)}$, found decreased iron absorption in patients with Crohn disease, studying a sample from 5 to 25 years old.

One limitation of this study would be the size of the sample, which would be considered quite small, especially concerning the number of participants in each of the four groups: conventional therapy, infliximab, remission, and control. For example, the concentration of sTfR was higher in both groups - conventional and infliximab - compared to the remission and control groups, but there was an only statistical difference of the infliximab group.

\section{CONCLUSION}

In conclusion, there were some contradictions among the different body iron status indicators and inflammation indicators at 2 and 6 months of treatment with conventional and infliximab 
therapy, however after one year of treatment, as shown by the remission group, all indicators studied, except transferrin, were similar to healthy children and adolescents.

\section{Authors' contribution}

Corrêa FF: development of the pre-project and all of the research stages (review of the literature, data collection, data analysis, and composition). Sdepanian VL: development of the preproject and all of the research stages (review of the literature, data collection, data analysis, composition, supervision, and guidance).

\section{Orcid}

Fernanda Ferreira Corrêa: 0000-0001-9375-495X.

Vera Lucia Sdepanian: 0000-0003-2614-710X.

Corrêa FF, Sdepanian VL. Indicadores do estado corporal do ferro e indicadores de inflamação durante o tratamento da doença inflamatória intestinal em crianças e adolescentes. Arq Gastroenterol. 2021;58(1):48-54.

Resumo - Contexto - O tratamento de pacientes com doença inflamatória intestinal (DII) consiste na indução e manutenção da remissão da doença. Os indicadores do estado corporal do ferro seriam úteis para o diagnóstico da anemia por deficiência de ferro, enquanto os indicadores de inflamação para o diagnóstico da anemia da doença crônica. Objetivo - Avaliar os indicadores do estado corporal do ferro e os indicadores de inflamação durante o tratamento da doença inflamatória intestinal, com terapia convencional ou infliximabe em crianças e adolescentes. Métodos - Estudo de casocontrole de uma amostra de 116 indivíduos, sendo 81 pacientes com DII, dos quais 18 com terapia convencional, 20 infliximabe e 43 em remissão da doença, e 35 crianças e adolescentes saudáveis (grupo controle). Os indicadores do estado do ferro e os indicadores de inflamação foram avaliados no

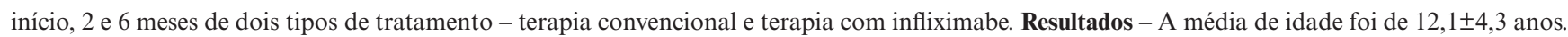
No início do tratamento, ambos os grupos - terapia convencional e infliximabe - apresentaram diferenças significantes com relação à maioria dos marcadores estudados comparados ao grupo controle. Após 2 meses de terapia convencional, os níveis de hemoglobina e ferro sérico foram inferiores em comparação ao grupo controle; e amplitude de distribuição dos eritrócitos (RDW), capacidade total de ligação do ferro, razão entre o receptor de transferrina solúvel e ferritina e interleucina-6 foram superiores aos do grupo controle. Após 2 meses de tratamento com infliximabe os níveis de hemoglobina e ferro sérico foram inferiores em comparação ao grupo controle, e RDW, receptor de transferrina solúvel e interleucina-6 foram superiores aos do grupo controle. Após 6 meses de terapia convencional, os níveis de hemoglobina e ferro sérico foram inferiores aos do grupo controle, e RDW e interleucina-6 superiores aos do grupo controle. Após 6 meses de tratamento com infliximabe, os níveis de hemoglobina e ferro sérico foram inferiores comparados ao grupo controle, e RDW, receptor de transferrina solúvel, razão receptor de transferrina solúvel e ferritina, taxa de sedimentação de eritrócitos e plaquetas foram superiores ao do grupo controle. Quanto aos pacientes que estavam em tratamento há mais de um ano (grupo remissão), todos os marcadores, exceto a transferrina, foram similares ao grupo controle. Conclusão - Houve contradições entre os diferentes indicadores do estado corporal do ferro e dos indicadores de inflamação aos 2 e 6 meses de tratamento com terapia convencional e infliximabe, no entanto após um ano de tratamento, conforme observado pelo grupo em remissão, todos os indicadores estudados, exceto a transferrina, foram semelhantes aos das crianças e adolescentes saudáveis.

DESCRITORES - Doenças inflamatórias intestinais, terapia. Anemia ferropriva. Criança. Adolescente.

\section{REFERENCES}

1. Louis E, Collard A, Oger AF, Degroote E, Aboul Nasr El Yafi FA, Belaiche J. Behaviour of Crohn's disease according to the Vienna classification: changing pattern over the course of the disease. Gut. 2001;49:777-82.

2. Cosnes J, Cattan S, Blain A, Beaugerie L, Carbonnel F, Parc R, et al. Longterm evolution of disease behavior of Crohn's disease. Inflamm Bowel Dis. 2002;8:24450.

3. Hellers G, Bergstrand O, Ewerth S, Holmstrom B. Occurrence and outcome after primary treatment of anal fistulae in Crohn's disease. Gut. 1980;21:525-7.

4. Mekhjian HS, Switz DM, Melnyk CS, Rankin GB, Brooks RK. Clinical features and natural history of Crohn's disease. Gastroenterology. 1979;77:898-906.

5. Reenaers C, Belaiche J, Louis E. Impact of medical therapies on inflammatory bowel disease complication rate. World J Gastroenterol. 2012;18:3823-7.

6. Turner D, Ruemmele FM, Orlanski-Meyer E, Griffiths AM, Carpi JM, Bronsky J, Veres G, et al. Management of Paediatric Ulcerative Colitis, Part 1: Ambulatory Care-An Evidence-based Guideline from European Crohn's and Colitis Organization and European Society of Paediatric Gastroenterology, Hepatology and Nutrition. J Pediatr Gastroenterol Nutr. 2018;67:257-91.

7. Ruemmele FM, Veres G, Kolho KL, Griffiths A, Levine A, Escher JC, et al. Consensus guidelines of ECCO/ESPGHAN on the medical management of pediatric Crohn's disease. J Crohns Colitis. 2014;8:1179-207.

8. Kuvibidila S, Warrier RP, Ode D, Yu L. Serum transferrin receptor concentrations in women with mild malnutrition. Am J Clin Nutr. 1996;63:596-601.

9. Stein J, Dignass AU. Management of iron deficiency anemia in inflammatory bowel disease - a practical approach. Ann Gastroenterol. 2013;26:104-13.
10. Kaitha S, Bashir M, Ali T. Iron deficiency anemia in inflammatory bowel disease. World J Gastrointest Pathophysiol. 2015;6:62-72.

11. Revel-Vilk S, Tamary H, Broide E, Zoldan M, Dinari G, Zahavi I, et al. Serum transferrin receptor in children and adolescents with inflammatory bowel disease. Eur J Pediatr. 2000;159:585-9.

12. Olivares M, Walter T, Cook JD, Hertrampf E, Pizarro F. Usefulness of serum transferrin receptor and serum ferritin in diagnosis of iron deficiency in infancy. Am J Clin Nutr. 2000;72:1191-5.

13. Beguin Y. Soluble transferrin receptor for the evaluation of erythropoiesis and iron status. Clin Chim Acta. 2003;329:9-22.

14. Jain S, Narayan S, Chandra J, Sharma S, Jain S, Malhan P. Evaluation of serum transferrin receptor and STfR ferritin indices in diagnosing and differentiating iron deficiency anemia from anemia of chronic disease. Indian J Pediatr. 2010;77:179-83.

15. Pettersson T, Kivivuori SM, Siimes MA. Is serum transferrin receptor useful for detecting iron-deficiency in anaemic patients with chronic inflammatory diseases? Br J Rheumatol. 1994;33:740-4.

16. Yang Z, Dewey KG, Lönnerdal B, Hernell O, Chaparro C, Adu-Afarwuah S, et al. Comparison of plasma ferritina concentration with the ratio of plasma transferrin receptor to ferritin in estimating body iron stores: results of 4 intervention trials. Am J Clin Nutr.2008;87:1892-8.

17. Oustamanolakis $P$, Koutroubakis IE. Soluble transferrin receptor-ferritin indexis the most efficient marker for the diagnosis of iron deficiency anemia inpatients with IBD. Inflamm Bowel Dis. 2011;17:E158-9. 
18. Stein J, Hartmann F, Dignass AU. Diagnosis and management of iron deficiency anemia in patients with IBD. Nat Rev Gastroenterol Hepatol. 2010;7: 599-610.

19. Karaskova E, Volejnikova J, Holub D, Velganova-Veghova M, Sulovska L, Miha $\mathrm{V}$, et al. Hepcidin in newly diagnosed inflammatory bowel disease in children. J Paediatr Child Health. 2018;54:1362-7.

20. Aljomah G, Baker SS, Schmidt K, Alkhouri R, Kozielski R, Zhu L, et al. Anemia in Pediatric Inflammatory Bowel Disease. J Pediatr Gastroenterol Nutr. 2018;67:351-5.

21. Daude S, Remen T, Chateau T, Danese S, Gastin I, Baumann C, et al. Comparative accuracy of ferritin, transferrin saturation and soluble transferrin receptor for the diagnosis of iron deficiency in inflammatory bowel disease. Aliment Pharmacol Ther. 2020;51:1087-95.

22. Semrin G, Fishman DS, Bousvaros A, Zholudev A, Saunders AC, Correia CE, et al. Impaired intestinal iron absorption in Crohn's disease correlates with disease activity and markers of inflammation. Inflamm Bowel Dis. 2006;12:1101-6.

23. Lomer MC, Cook WB, Jan-Mohamed HJ, Hutchinson C, Liu DY, Hider RC, et al. Iron requirements based upon iron absorption tests are poorly predicted by haematological indices in patients with inactive inflammatory bowel disease. $\mathrm{Br}$ J Nutr. 2012;107:1806-11.

24. Gasche C, Waldhoer T, Feichtenschlager T, Male C, Mayer A, Mittermaier C, et al; Austrian Inflammatory Bowel Diseases Study Group. Prediction of response to iron sucrose in inflammatory bowel disease-associated anemia. Am J Gastroenterol. 2001;96:2382-7.

25. Krawiec P, Pac-Kożuchowska E. Soluble transferrin receptor and soluble transferrin receptor/log ferritin index in diagnosis of iron deficiency anemia in pediatric inflammatory bowel disease. Dig Liver Dis. 2019;51:352-7.

26. Hyams JS, Fitzgerald JE, Treem WR, Wyzga N, Kreutzer DL. Relationship of functional and antigenic interleukin 6 to disease activity in inflammatory bowel disease. Gastroenterology. 1993;104:1285-92.

27. Bartels U, Pedersen NS, Jarnum S. Iron absorption and serum ferritin in chronic inflammatory bowel disease. Scand J Gastroenterol. 1978;13:649-56.

28. Bergamaschi G, Di Sabatino A, Albertini R, Ardizzone S, Biancheri P, Bonetti E, et al. Prevalence and pathogenesis of anemia in inflammatory bowel disease Influence of anti-tumor necrosis factor-alpha treatment. Haematologica. 2010;95:199-205.

29. Kangaspunta M, Haapamäki J, Färkkilä M, Arkkila P. Inflammatory bowel disease and anemia: intravenous iron treatment. Scand J Gastroenterol. 2018;53:430-4.
30. Aksan A, Wohlrath M, Iqbal TH, Farrag K, Dignass A, Stein J. Serum Hepcidin Levels Predict Intestinal Iron Absorption in Patients with Inflammatory Bowel Disease. Clin Lab. 2019;65(3).

31. Danese S, Motte Cd Cde L, Fiocchi C. Platelets in inflammatory bowel disease: clinical, pathogenic, and therapeutic implications. Am J Gastroenterol. 2004;99:938-45.

32. World Health Organization (WHO). Iron deficiency anaemia: assessment, prevention, and control. A guide for programme managers. Geneva, 2001.

33. Pytrus T, Flis A, Iwańczak F, Iwańczak B. [The frequency of anemia in children with newly diagnosed Crohn's disease in children]. Pol Merkur Lekarski. 2013;34:263-8

34. Hyams JS, Ferry GD, Mandel FS, Gryboski JD, Kibort PM, Kirschner BS, et al. Development and validation of a pediatric Crohn's disease activity index. J Pediatr Gastroenterol Nutr. 1991;12:439-47.

35. Turner D, Otley AR, Mack D, Hyams J, de Bruijne J, Uusoue K, et al. Development, validation, and evaluation of a pediatric ulcerative colitis activity index: a prospective multicenter study. Gastroenterology. 2007;133:423-32.

36. Sdepanian VL, Silvestrini WS, de Morais MB. [Diagnostic limitations of the physical examination in the identification of children with anemia]. Rev Assoc Med Bras. 1996;42:169-74.

37. Malope BI, MacPhail AP, Alberts M, Hiss DC. The ratio of serum transferrin receptor and serum ferritin in the diagnosis of iron status. Br J Haematol. 2001;115:84-9.

38. Mattar RH, de Azevedo RA, Speridião PG, Neto UF, Morais MB. Estado nutricional e absorção intestinal de ferro em crianças com doença hepática crônica com e sem colestase. J Pediatr. 2005;81:317-24.

39. Gross SJ, Stuart MJ, Swender PT, Oski FA. Malabsorption of iron in children with iron deficiency. J Pediatr. 1976;88:795-9.

40. De Vizia B, Poggi V, Vajro P, Cucchiara S, Acampora A. Iron malabsorption in giardiasis. J Pediatr. 1985;107:75-8.

41. Levine A, Griffiths A, Markowitz J, Wilson DC, Turner D, Russell RK, et al. Pediatric modification of the Montreal classification for inflammatory bowe disease: the Paris classification. Inflamm Bowel Dis. 2011;17:1314-21.

42. Institute of medicine. National Research Council. Dietary Reference Intakes for vitamin $\mathrm{A}$, vitamin $\mathrm{K}$, arsenic, boron, chromium, copper, iodine, iron, manganese, molybdenum, nickel, silicon, vanadium, and zinc. Washington (DC): National Academy Press 2000.

43. Venturieri MO, Komati JTS, Lopes LHC, Sdepanian VL. Treatment with Nori-

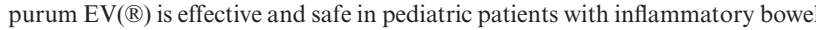
disease and iron deficiency anemia. Scand J Gastroenterol. 2019;54:198-204. 